\title{
SOME INTERESTING BIRD RECORDS FROM THE PAS, MANITOBA
}

\section{by Sam Waller, The Little Museum, The Pas, Manitoba}

Because of the close proximity of The Pas to the Saskatchewan border it has been suggested that I give some records of uncommon or unusual birds that have appeared in this area in the last few years, some of which have been substantiated by specimens.

Common Egret. Harold Wells, a competent observer, saw a white heron, possibly a Common Egret, on July 24, 1966 at Reader Lake, and possibly the same bird at Saskaram Lake in September. It flew into a tall elm tree and was very wary and difficult to approach. Others saw the bird, and we will watch for it again this year.

Ross' Goose. In my time two of these have been recorded at The Pas and one was sent to the Manitoba Museum about 1957 (it is now a mounted specimen).

Wood Duck. There is reason to believe they are slowly increasing in numbers. The first record was a dried head, given me by one of my school pupils at Cedar Lake, whose father, Chief Donald Easter, had shot it in September, 1951. Cedar Lake is about 56 miles southwest of The Pas as the crow flies, but it is now inundated by the waters of the Grand Rapids Dam. A second specimen, a beautiful male that had walked into a muskrat trap, was brought to me on May 4, 1957. When I moved back from Cedar Lake to live in The Pas, I examined two Wood Ducks shot by hunters in season, but neither would have made good study skins.

Oldsquaw. A putrid specimen was ibrought to me on September 26, 1947 by Ged Reader of Reader Lake, nine miles north of The Pas. It was made into a fair study skin and is now in the Little Museum (my private museum, always open to the public).
Harlequin Duck. Two were shot by an Indian on September 15, 1950; one is in the collection of the Little Museum and the other is in the Manitoba Museum.

American Avocet. Two of these birds were seen by Harold Wells late in May, 1962, but they were not collected and no pictures were taken for positive record.

Glaucous Gull. A male was taken at Reader Lake on October 15, 1946 by Ged Reader and is a study skin in the Little 'Museum. It was positively identified by James L. Baillie of the Royal Ontario Museum, Toronto.

Starling. Starlings were long ago recorded as far north as the port of Churchill, but on August 26, 1965 a dead bird was discovered in a chimney of an abandoned Hudson's Bay post at Duck Lake, 140 miles northwest of Churchill, by biologist Don Miller and brought to The Pas where it was preserved by chemicals as it was too mummified to skin.

Summer Tanager. One was picked up by water control officer Harvey Anderson on May 25, 1966, who found the bird dead on the shore of Rahl's island and the Saskatchewan River adjacent to the town of The Pas. It was brought to me later by two conservation officers, Eddie Engen and Bill Moshenko, but I had never seen the species before and could not identify it positively. I prepared it as a study skin and sent it to W. Earl Godfrey at Ottawa, who identified it as a Summer Tanager, a male assuming first nuptial plumage, referable to the race Piranga rubra rubra, the first record for Canada west of southern Ontario. Godfrey reported this record in the Canadian Field-Naturalist $(80: 254)$, and this record is also mentioned in Godfrey's new Birds of Canada (1966). 